\title{
Antineoplastic Protein Inhibitor
}

National Cancer Institute

\section{Source}

National Cancer Institute. Antineoplastic Protein Inhibitor. NCI Thesaurus. Code C129824.

Any agent that inhibits the activity of any protein that is involved in cancer-specific pathways. An antineoplastic protein inhibitor is a specific cancer cell-targeting agent. 